\title{
Assessment of bacterial and fungal (hemi)cellulose-degrading enzymes in saccharification of ammonia fibre expansion-pretreated Arundo donax
}

\author{
Simona Giacobbe ${ }^{1} \cdot$ Venkatesh Balan $^{2} \cdot$ Salvatore Montella $^{1} \cdot$ Massimo Fagnano $^{3}$. \\ Mauro Mori ${ }^{3}$ - Vincenza Faraco ${ }^{1}$
}

Received: 2 July 2015 /Revised: 1 October 2015 / Accepted: 7 October 2015 /Published online: 31 October 2015

(C) The Author(s) 2015. This article is published with open access at Springerlink.com

\begin{abstract}
This study reports enzymatic hydrolysis of the biomass of the giant reed (Arundo donax L.) after ammonia fibre expansion (AFEX) pretreatment. In particular, the capacity of the arabinofuranosidase from the fungus Pleurotus ostreatus recombinantly expressed in Pichia pastoris rPoAbf, its evolved mutant $\mathrm{rPoAbf} \mathrm{F} 435 \mathrm{Y} / \mathrm{Y} 446 \mathrm{~F}$ and the endocellulase from Streptomyces sp. G12 CelStrep recombinantly expressed in Escherichia coli to enhance the hydrolysis of AFEX-treated A. donax was investigated, using the corn stover as reference feedstock. The investigated enzymes were assayed using a mixture of purified cellulases (CBHI, CBHII, EGI and $\beta \mathrm{G}$ ), endoxylanases (LX3, LX4) and accessory hemicellulases (LarbF and $\mathrm{L} \beta \mathrm{X}$ ) as reference enzyme mixture and substituting EGI with rCelStrep and LarbF with rPoAbf or rPoAbf F435Y/Y446F. The use of rPoAbf F435Y/ $\mathrm{Y} 446 \mathrm{~F}$ in the substitution of LarbF led to improvements in sugar conversion, giving a glucan, xylan and arabinan conversion after $72 \mathrm{~h}$ of around 62,63 and $80 \%$, respectively, similar or higher than those (44, 66 and $55 \%$ ) achieved by $72 \mathrm{~h}$ hydrolysis with commercial enzymes Novozymes Cellic ${ }^{\circledR}$, Ctec 3 and Htec3. The enzymes rPoAbf, rPoAbf F435Y/ $\mathrm{Y} 446 \mathrm{~F}$ and $\mathrm{rCelStrep}$ were also investigated for their effect
\end{abstract}

Vincenza Faraco

vfaraco@unina.it

1 Department of Chemical Sciences, University of Naples "Federico II", Complesso Universitario Monte S. Angelo, via Cintia, Napoli, Italy

2 Department of Chemical Engineering and Materials Science, DOE Great Lakes Bioenergy Research Center, Michigan State University, Lansing, MI 48823, USA

3 Department of Agriculture, University of Naples "Federico II", Portici, Napoli, Italy on hydrolysis of AFEX-pretreated A. donax by addition to commercial enzyme mixture Novozymes Cellic ${ }^{\circledR}$, Ctec3 and Htec3, and it was shown that the addition of rPoAbf and its evolved mutant rPoAbf F435Y/Y446F enhanced both xylan and arabinan conversions, which achieved $80 \%$ after 6 days of saccharification with $\mathrm{rPoAbf}$ F435Y/Y446F.

Keywords Lignocellulose $\cdot$ Pretreatment $\cdot$ Cellulase $\cdot$ Arabinofuranosidase

\section{Introduction}

The policies for climate change mitigation promote the replacement of fossil fuels and petroleum-based products with alternative bioproducts from renewable resources such as biomass crops (Kajaste 2014). However, the incentives given to produce energy crops could have devastating effects on agricultural markets, as several food grain-producing lands will be taken away, reducing food production and consequently increasing food prices (Scheidel and Sorman 2012).

To avoid any competition for land between food and nonfood crops, several efforts are under way to use crop lands not suitable for the traditional food crops for growing dedicated energy crops.

In Mediterranean environments, hilly areas are considered not appropriate for the traditional cereal production because yield and gross income are very low and because the traditional cropping system (deep soil tillage at the end of August and sowing in November) causes extreme vulnerability to soil erosion (Diodato et al. 2009, 2011; Fagnano et al. 2012). In these conditions, perennial biomass crops such as the giant reed (Arundo donax L.) proved to reduce soil erosion and to increase the potential gross income of farmers (Fagnano et al. 
2015), with favourable environmental impacts (Forte et al. 2015).

The giant reed (A. donax L.) is also suggested for other areas not suitable for food crops such as polluted soils since it acts as a phyto-remediating agent and it also allows the production of large amounts of cellulose and hemicellulose (Fiorentino et al. 2010, 2013).

Many studies have shown that sugar polymers (cellulose and hemicellulose) present in biomasses can be hydrolyzed into fermentable sugars and then converted into fuels and chemicals (Wettstein et al. 2012; Kobayashi and Fukuoka 2013; Kajaste 2014). The Pacific Northwest National Laboratory (PNNL) and National Renewable Energy Laboratory (NREL) identified 12 building blocks produced through sugar conversions which could be used to obtain a variety of high-value biobased products. These include succinic acid, glucaric acid, aspartic acid, glycerol, sorbitol and xylitol/arabinitol (Hermann et al. 2007).

The production of bioproducts from lignocellulosic biomass requires several steps (Kumar et al. 2009), including an initial pretreatment step needed to break the lignin barrier and make cellulose and hemicellulose accessible to the enzymes during the hydrolysis to produce fermentable sugars. Enzymatic hydrolysis of sugar polymers using biomassdegrading enzymes such as cellulase and hemicellulase is preferred over dilute acid hydrolysis because of the higher conversion and lower environmental impact (Taherzadeh and Keikhosro 2007). Due to the complexity of the polysaccharides of the pretreated biomass, a tailor-made enzyme cocktail is required to achieve a more efficient saccharification (Gao et al. 2010a, 2011). Besides the enzymes involved in the hydrolysis of cellulose and the backbone of hemicellulose, some other enzymes with hydrolytic ability towards glycoside branches in hemicellulose were proven to improve the overall monosaccharide yield.

This study was aimed at evaluating the conversion of A. donax into monosaccharides for bioethanol or bioproducts production by enzymatic hydrolysis of the polysaccharides issued from pretreatment of the biomass by ammonia fibre expansion (AFEX). To the best of our knowledge, this is the first manuscript on saccharification of AFEX-pretreated A. donax.

In particular, the capacity of the cellulase CelStrep from Streptomyces sp. G12 recombinantly expressed in Escherichia coli (Amore et al. 2012b) and $\alpha$-Larabinofuranosidase PoAbf from the fungus Pleurotus ostreatus recombinantly expressed in Pichia pastoris (Amore et al. 2012a) and its evolved mutant rPoAbf F435Y/ Y446F (Giacobbe et al. 2014) to improve the sugar yields of AFEX-pretreated $A$. donax was investigated. The rPoAbf F435Y/Y446F mutant had been previously developed with the aim to improve the catalytic efficiency of the investigated $\alpha$-L-arabinofuranosidase (Giacobbe et al. 2014). It was further investigated in biomass conversion due to its ability to hydrolyze both soluble and insoluble substrates better than that of the rPoAbf wild type. Differently from our previous work (Marcolongo et al. 2014), the investigated enzymes were used in combination with purified fungal and bacterial enzymes to define a tailor-made enzyme cocktail for $A$. donax hydrolysis in order to reduce the cost of the enzymatic saccharification process.

\section{Materials and methods}

\section{Feedstock}

Biomasses used in this study for pretreatment and saccharification experiments include corn stover and the giant reed (A. donax L.). A. donax was produced in marginal lands of southern Italy with a low-input cropping system (Forte et al. 2015), and corn stover was provided by Michigan State University (MSU). The biomasses were milled with a 2-mmdiameter sieve and stored under dry conditions at room temperature until further use. The moisture content was measured using a moisture analyser (Sartorius MA35M, Elk Grove, IL).

\section{Compositional analysis}

Compositional analyses of $A$. donax and corn stover biomasses were performed following the National Renewable Energy Laboratory (NREL) Laboratory Analytical Procedures (LAPs) standard protocols:

- "Preparation of samples for compositional analysis" (Hames et al. 2008)

- "Determination of structural carbohydrates and lignin in Biomass"

- "Determination of Total Solids in Biomass and Total Dissolved Solids in Liquid Process Samples" (Sluiter et al. 2008)

- "Determination of Ash in Biomass" (Sluiter et al. 2005b)

- "Determination of structural carbohydrates and lignin in biomass" (Sluiter et al. 2005a)

Monomeric sugars were quantified using a Bio-Rad Aminex HPX-87H high-performance liquid chromatography (HPLC) column using $5 \mathrm{mM}$ sulphuric acid as mobile phase.

The variability between experiments is reflected by the standard deviation reported.

\section{AFEX pretreatment}

Corn stover and A. donax were pretreated through the AFEX method by varying the ammonia to biomass ratio (1:1 and $2: 1)$, reaction temperature $\left(100-160{ }^{\circ} \mathrm{C}\right)$, moisture $(60$ 
$233 \%$ on dry weight basis) and fixed residence time (15 min). AFEX was carried out in a high-pressure stainless steel vessel. Biomass was first loaded into the vessel with appropriate moisture after taking into consideration the moisture content of original biomass. Then, the reactor was closed and vacuum applied to remove residual air in the reactor. The required amount of liquid ammonia was loaded into the reactor using an ammonia delivery pump. The vessel was heated by an external mantle and the biomass was mixed during the AFEX process for $15 \mathrm{~min}$. As the temperature of the reactor increased, the pressure in the vessel rose (between 200 and 400 psi) depending on the ammonia to biomass loading. The pressure was released from the vessel and ammonia was vented in a fume hood. The pretreated biomass was moved to a tray and dried in a fume hood overnight to remove residual ammonia. Then, dry AFEX-treated biomass was stored in a sealed polythene bag at $4{ }^{\circ} \mathrm{C}$ until further use.

\section{Purified enzymes and their source}

The following purified enzymes were tested in this study:

- Fungal cellobiohydrolase I (CBH I; glycoside hydrolase (GH) family 7A), cellobiohydrolase II (CBH II; GH family 6A) and endoglucanase I (EG I; GH family 7B) were purified from Spezyme CP using several chromatography steps (size-exclusion chromatography, anion and cation exchange chromatography, hydrophobic interaction chromatography and affinity chromatography) as described in Gao et al. (2010a). The enzymes were used at a concentration of $3.32 \mathrm{mg} / \mathrm{g}$ glucan each.

- Fungal $\beta$-glucosidase ( $\beta \mathrm{G}$; GH family 3 ) was purified from Novozyme 188 using anion exchange chromatography followed by cation exchange chromatography as described in Gao et al. (2010a) and used at a concentration of $2 \mathrm{mg} / \mathrm{g}$ glucan.

- Bacterial xylanases (LX3, GH family 10; LX4, GH family 11) from Clostridium thermocellum library (Gao et al. 2011) (bacterial cell concentrate was a kind gift of Dr. Paul Weimer, United States Department of Agriculture, Agricultural Research Service, United States Dairy Forage Research Center, WI, USA) were recombinantly expressed in E. coli and purified using HIS-select nickel affinity chromatography. The enzymes were used at a concentration of $1.66 \mathrm{mg} / \mathrm{g}$ glucan each.

- Bacterial $\beta$-xylosidase (L $\beta X ; \mathrm{GH}$ family 52) from Geobacillus stearothermophilus XYNB2 (Gao et al. 2010b) was recombinantly expressed in E. coli and purified using HIS-select nickel affinity chromatography. The enzyme was used at $0.6 \mathrm{mg} / \mathrm{g}$ glucan.

- Bacterial $\alpha$-arabinofuranosidase (LarbF, GH family 51) from Geobacillus sp. G11MC16 was recombinantly expressed in E. coli and purified using HIS-select nickel affinity chromatography. The enzyme was loaded at $0.6 \mathrm{mg} / \mathrm{g}$ glucan (Gao et al. 2011).

- Bacterial CelStrep (EMBL accession number HE862416) from Streptomyces sp. G12 was recombinantly expressed in $E$. coli (Amore et al. 2012b). The enzyme was purified by ammonium sulphate precipitation followed by hydrophobic interaction chromatography, as described in Amore et al. (2012b) and used at $3.32 \mathrm{mg} / \mathrm{g}$ glucan.

- Fungal $\alpha$-L-arabinofuranosidase (rPoAbf) from P. ostreatus (ATCC 66376) was recombinantly expressed in $P$. pastoris (Amore et al. 2012a). The enzyme was purified by ammonium sulphate precipitation followed by hydrophobic interaction chromatography, as described in Amore et al. (2012a) and loaded at $0.6 \mathrm{mg} / \mathrm{g}$ glucan.

- The variant F435Y/Y446F of PoAbf, previously selected from a directed evolution library of rPoAbf, was recombinantly expressed in $P$. pastoris (Giacobbe et al. 2014), purified as rPoAbf wild type and loaded at $0.6 \mathrm{mg} / \mathrm{g}$ glucan.

\section{Determination of protein concentration}

Purified protein concentration was determined by the Pierce (Pierce Biotechnology, Rockford, USA) bicinchoninic acid (BCA) assay kit following the manufacturer's instructions. Bovine serum albumin (BSA) was used as standard.

\section{Enzymatic hydrolysis}

The bioconversion experiments were performed in five vials at $1 \%(w / w)$ glucan loading in $50 \mathrm{mM}$ citrate buffer $(\mathrm{pH} 4.8)$ with the desired enzymes. $0.5 \mathrm{mM}$ sodium azide was used to prevent microbial and fungal growth. The saccharification was performed at $50{ }^{\circ} \mathrm{C}$ and $250 \mathrm{rpm}$ in a shaking incubator. Sampling was done every $24 \mathrm{~h}$ to evaluate the sugar composition using high-performance liquid chromatography (HPLC) system. The commercial enzyme mixture Novozymes Cellic ${ }^{\circledR}(60 \%$ Ctec3 and $40 \%$ Htec3) was used (at a loading of $15 \mathrm{mg} / \mathrm{g}$ of glucan) for saccharification experiments to evaluate the best pretreatment conditions. The hydrolysis of AFEX-treated biomasses was performed with the following enzymes at a loading of around $16.5 \mathrm{mg} / \mathrm{g}$ glucan (Table 1). An enzymatic mixture named mix A was prepared, including $\mathrm{CBH}$ I, cellobiohydrolase II, EG I at a concentration of $3.32 \mathrm{mg} / \mathrm{g}$ glucan each, $\beta \mathrm{G} 2 \mathrm{mg} / \mathrm{g}$ glucan, xylanases (LX3, LX4) $1.66 \mathrm{mg} / \mathrm{g}$ glucan each and L $\beta X$ and LarbF $0.6 \mathrm{mg} / \mathrm{g}$ glucan each. In mix B, the EG I was replaced by cellulase rCelStrep; in mix $\mathrm{C}$, the LarbF was replaced by the rPoAbf; in mix D, the LarbF was replaced by a mutant of $r$ PoAbf named rPoAbf F435Y/Y446F; in mix E, both EGI and LarbF were replaced by rCelStrep and $\mathrm{rPoAbf}$; in mix $\mathrm{F}$, both EGI and LarbF were replaced by rCelStrep and rPoAbf F435Y/Y446F. 
Table 1 Mixtures of bacterial and fungal enzymes tested on AFEX-treated biomasses

Individual enzyme loading (mg/g glucan)

\begin{tabular}{llllllllllll}
\hline Mix & CBHI & CBHII & $\beta G-$ & LX3 & LX4 & L $\beta X$ & EGI & LarbF & rCelstrep & rPoAbf & rPoAbf F435Y/Y446F \\
\hline A & 3.32 & 3.32 & 2 & 1.66 & 1.66 & 0.6 & 3.32 & 0.6 & & \\
B & 3.32 & 3.32 & 2 & 1.66 & 1.66 & 0.6 & & 0.6 & 3.32 & 0.6 & 0.6 \\
C & 3.32 & 3.32 & 2 & 1.66 & 1.66 & 0.6 & 3.32 & & & 0.6 & 0.6 \\
D & 3.32 & 3.32 & 2 & 1.66 & 1.66 & 0.6 & 3.32 & & & \\
E & 3.32 & 3.32 & 2 & 1.66 & 1.66 & 0.6 & & 0.6 & 3.32 & 0.6 \\
F & 3.32 & 3.32 & 2 & 1.66 & 1.66 & 0.6 & & 0.6 & \\
\hline
\end{tabular}

Moreover, rCelStrep (3.32 mg/g glucan), rPoAbf $(0.6 \mathrm{mg} / \mathrm{g}$ glucan) and $\mathrm{rPoAbf}$ mutant $(0.6 \mathrm{mg} / \mathrm{g}$ glucan $)$ were added to the commercial mixture Novozymes Cellic ${ }^{\circledR}$.

\section{Sugar analysis}

About $200 \mu \mathrm{l}$ hydrolysate collected at different times during enzyme hydrolysis was transferred to a centrifuge tube, heated to $100{ }^{\circ} \mathrm{C}$ for $10 \mathrm{~min}$ (to denature the enzymes), centrifuged at $8000 \mathrm{rpm}$ for $10 \mathrm{~min}$ to remove the precipitates and then stored in a HPLC vial at $-20{ }^{\circ} \mathrm{C}$ until further use. A BioRad Aminex HPX-87P HPLC column was used to determine the monomeric sugar concentrations in the hydrolysate. All experiments were performed in triplicate. Shimadzu HPLC Prominence system (Columbia, MD, USA) with a refractive index detector (RID), was employed for analysing the sugars. Water was the mobile phase at a fixed flow rate of $0.6 \mathrm{ml} / \mathrm{min}$, with isocratic elution. The column temperature was maintained at $60^{\circ} \mathrm{C}$, and the HPLC sample injection volume was $20 \mu \mathrm{l}$. Standard curves were generated using different concentrations of mixed sugars. A guard column with similar packing was used throughout the chromatography experiments.

\section{Statistical analyses}

One-way ANOVA followed by Tukey's HSD post hoc for pairwise comparison of means (at $P \leq 0.05$ ) was used to assess the difference in the sugar conversion of the different enzyme mixtures used to hydrolyze $A$. donax or corn stover biomass. Statistical analyses were performed using SPSS 13.0 statistical software package (SPSS Inc., Cary, NC, USA).

\section{Results}

\section{Characterization of biomasses}

Analyses of the macromolecular composition of the unpretreated biomasses A. donax and corn stover were performed, and the results, reported in Table 2 , revealed that $A$. donax contains $61.41 \%$ of structural polysaccharides, $26.24 \%$ Klason lignin and $4.9 \%$ ash, while corn stover contains $63.23 \%$ of structural polysaccharides, $20.06 \%$ Klason lignin and $6.17 \%$ ash. Both the analysed biomasses contain significant percentages of $\mathrm{C} 5$ sugars mainly represented by xylan $(\sim 20 \%)$ while arabinan represents only around $2 \%$ of total dry weight and the C6 sugars consist mainly of glucan $(>37 \%)$.

\section{Selection of AFEX pretreatment conditions}

The yield of monosaccharides released during hydrolysis depends on various AFEX parameters such as moisture content, ammonia to biomass loading, residence time and temperature. Therefore, in order to assess the best pretreatment conditions for A. donax, three different AFEX treatments were carried out (Table 3 ). The AFEX-tested conditions, condition 1, condition 2 and condition 3 reported in Table 3, were chosen since they had been previously identified as the best conditions for the AFEX pretreatment of Miscanthus x giganteus (Murnen et al. 2007), corn stover (Balan et al. 2009b) and switchgrass (Bals et al. 2010), respectively. Since corn stover was used as the

Table 2 A. donax and corn stover composition before AFEX pretreatment (standard deviation obtained from three independent experiments)

\begin{tabular}{lll}
\hline Composition & $\begin{array}{l}\text { A. donax } \\
(\%, \text { dry weight basis })\end{array}$ & $\begin{array}{l}\text { Corn stover } \\
(\%, \text { dry weight basis })\end{array}$ \\
\hline Moisture content & $6.0 \pm 0.5$ & $8.7 \pm 0.6$ \\
Ash & $4.9 \pm 0.6$ & $6.7 \pm 1.0$ \\
Structural carbohydrate & & \\
$\quad$ Glucan & $38.0 \pm 0.0$ & $38.41 \pm 0.1$ \\
$\quad$ Xylan & $21.0 \pm 0.1$ & $19.9 \pm 1.0$ \\
Galactan & $1 \pm 0.1$ & $1.4 \pm 0.1$ \\
Arabinan & $1.5 \pm 0.0$ & $2.5 \pm 0.2$ \\
$\quad$ Mannan & N.D. & N.D. \\
Lignin & & \\
Acid-insoluble lignin & $26.2 \pm 0.1$ & $20.1 \pm 0.7$ \\
Acid-soluble lignin & $1.9 \pm 0.0$ & $2.0 \pm 0.3$ \\
\hline
\end{tabular}

$N D$ Not determined 
reference biomass in this study, the best AFEX condition for pretreatment of this biomass was tested to pretreat $A$. donax. Nevertheless, since $M$. $\mathrm{x}$ giganteus and switchgrass are perennial crops like $A$. donax, the best conditions for their AFEX pretreatment were also tested. The samples of $A$. donax pretreated in the different conditions were then enzymatically hydrolyzed for $168 \mathrm{~h}$ using a commercial enzymatic preparation consisting of Novozymes Cellic ${ }^{\circledR}, 60 \%$ Ctec 3 and $40 \%$ Htec3. In Table 3, the glucan and xylan conversions obtained after 24, 72 and $168 \mathrm{~h}$ of enzymatic hydrolysis of $A$. donax after the three different AFEX pretreatments are reported in comparison to corn stover. Both glucan and xylan hydrolyses reached their maximum level with AFEX pretreatment condition 2: $130{ }^{\circ} \mathrm{C}, 1 \mathrm{~kg}$ ammonia/ $1 \mathrm{~kg}$ dry biomass and $60 \%$ of moisture content. Based on these data, this condition was selected for further hydrolysis experiments.

\section{Saccharification of $A$. donax and corn stover using purified enzyme cocktail and commercial enzyme cocktail}

The enzymatic hydrolysis of biomass using commercial enzymes is not appropriate to evaluate the role of individual enzymes involved in the process, and it is difficult to obtain a tailor-made enzyme cocktail for the biomass of interest. Previous works have shown that an optimal cocktail of cellulolytic enzymes (CBH I, CBH II, EGI, $\beta \mathrm{G}$ ) and a set of hemicellulases and accessory enzymes (LX3, LX4, LarbF, $\mathrm{L} \beta \mathrm{X}$ ) are required to improve the hydrolysis of AFEXtreated corn stover (Gao et al. 2010a, 2011). Based on these results, the enzyme mix A (CBH I, CBH II, EGI, $\beta \mathrm{G}, \mathrm{LX} 3$, $\mathrm{LX} 4$, LarbF, L $\beta X$ ), previously optimized for corn stover (Gao et al. 2011), was used as reference enzymatic mixture to hydrolyze $A$. donax. Figure 1 shows the glucan, xylan and arabinan conversion percentages from corn stover and A. donax after AFEX treatment in selected condition 2, by 24- and 72-h-long hydrolyses with mix A.

As far as A. donax is concerned, although the enzyme mix A gave similar xylan hydrolysis ( $~ 63 \%$ after $72 \mathrm{~h}$ ) compared with the commercial enzymatic preparation, Novozymes Cellic ${ }^{\circledR}, 60 \%$ Ctec3 and $40 \%$ Htec3, reported in Table 2, lower glucan hydrolysis was achieved (less than $30 \%$ after $72 \mathrm{~h}$ ). As regards corn stover, mix A gave sugar conversions (Fig. 1) similar to those obtained with the Novozyme Cellic ${ }^{\circledR}$ enzyme cocktail (Table 3).

\section{Effect of the enzymes rCelStrep, rPoAbf and its variant on saccharification of $A$. donax and corn stover in comparison with the enzymes EGI or LarbF}

The effect of the arabinofuranosidase from the fungus $P$. ostreatus recombinantly expressed in P. pastoris $\mathrm{rPoAbf}$, its evolved mutant expressed in the same yeast $\mathrm{rPoAbf}$ 


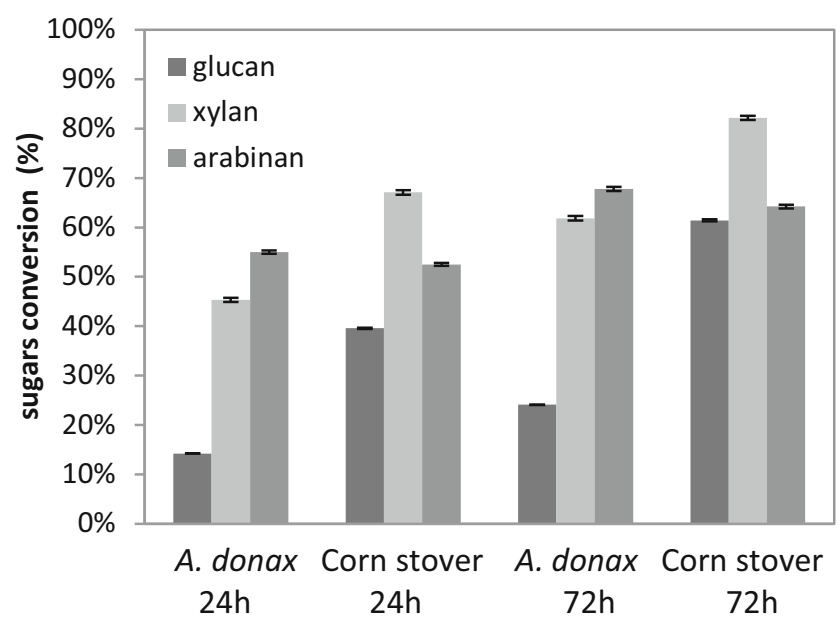

Fig. 1 Glucan, xylan and arabinan conversion after 24 and $72 \mathrm{~h}$ of hydrolysis on AFEX-treated corn stover and A. donax using the enzyme mix A containing the cellulases CBH I, CBH II and EG I loaded at $3.32 \mathrm{mg} / \mathrm{g}$ glucan each, $\beta \mathrm{G}$ loaded at $2 \mathrm{mg} / \mathrm{g}$ glucan, and the endoxylanases LX3 and LX4 and accessory hemicellulases LarbF and $\mathrm{L} \beta \mathrm{X}$ loaded at 1.66 and $0.6 \mathrm{mg} / \mathrm{g}$ glucan each, respectively

F435Y/Y446F and the cellulase from Streptomyces sp. G12 rCelStrep recombinantly expressed in $E$. coli in bioconversion of AFEX-pretreated A. donax and corn stover was tested. In these experiments, the enzyme mix A, containing cellulases (CBHI, CBHII, EGI and $\beta \mathrm{G}$ ), endoxylanases (LX3, LX4) and accessory hemicellulases ( $\mathrm{LarbF}$ and $\mathrm{L} \beta \mathrm{X}$ ), was used as reference enzyme mixture, and the effect of substituting EGI with rCelStrep and LarbF with rPoAbf or rPoAbf F435Y/ Y446F was assessed. In more detail, the bacterial cellulase rCelStrep was used instead of the fungal endoglucanase EGI in the enzyme mix B while the fungal arabinofuranosidases rPoAbf was used instead of the bacterial arabinofuranosidase LarbF in the enzyme mix $\mathrm{C}$. The evolved variant of $\mathrm{rPoAbf}$ (rPoAbf F435Y/Y446F) was used instead of the bacterial arabinofuranosidase LarbF in the enzyme mix D due to its ability to hydrolyze both soluble and insoluble substrates better than that of the rPoAbf wild type. Moreover, rCelStrep was also tested in combination with $\mathrm{rPoAbf}$ (mix E) or its variant (mix F) to check a possible synergism between bacterial and fungal enzymes.

Table 4 summarizes the conversion results of AFEXpretreated A. donax biomass using different purified enzymatic mixtures. The sugar conversion results showed that the substitution of EGI with rCelstrep (mix B) gave significantly higher glucan conversion ( $28 \%$ ) after $72 \mathrm{~h}$ than that obtained with enzyme mix A (24.1\%), corresponding to $15 \%$ increase in sugar conversion. On the other hand, the use of rCelstrep (mix B) decreased arabinan hydrolysis, giving an arabinan conversion $17 \%$ lower than that obtained with the enzyme mix A after $72 \mathrm{~h}$.

When the rPoAbf wild type was used instead of LarbF (mix C), no significant differences in glucan and xylan hydrolyses were observed. The use of rPoAbf wild type gave an arabinan hydrolysis $14 \%$ significantly lower than that obtained with mix A after $72 \mathrm{~h}$ hydrolysis.

The use of rPoAbf F435Y/Y446F instead of LarbF (enzyme mix D in comparison with enzyme mix A) and the wild-type $\mathrm{rPoAbf}$ (mix D in comparison with mix C) led to improvements in sugar conversion. The use of mix $\mathrm{D}$ gave $60 \%$ glucan conversion after $72 \mathrm{~h}$, which is 2.5 times higher than that reached with mix A and mix C. The use of mix D gave $53 \%$ xylan conversion after $24 \mathrm{~h}$, which is $16 \%$ higher than that obtained with mix A. Moreover, the xylan conversion after $72 \mathrm{~h}$ saccharification with mix D achieved $63 \%$, similar to that obtained with mix A and mix $\mathrm{C}$. The arabinan conversion was found to be $78 \%$ after $72 \mathrm{~h}$, which is 15 and $26 \%$ higher than that obtained with the mix A and mix C, respectively (Fig. 2).

The effect of rCelstrep in combination with $\mathrm{rPoAbf}$ (mix E) and $\mathrm{rPoAbf} \mathrm{F} 435 \mathrm{Y} / \mathrm{Y} 446 \mathrm{~F}$ (mix F) was also analysed (Table 4). After $24 \mathrm{~h}$, glucan conversion was found to be not significantly higher than mix A, for both mix $\mathrm{E}$ and mix $\mathrm{F}$. However, about $20 \%$ glucan conversion was obtained after $72 \mathrm{~h}$ for enzyme mix E, which is $14.5 \%$ lower than that obtained with enzyme mix A; also, the xylan conversion resulted significantly lower than that with enzyme mix A after $72 \mathrm{~h}$ hydrolysis. As regards mix F, no significant differences with enzyme mix A were found in xylan hydrolysis after both 24 and $72 \mathrm{~h}$. Mix E gave 20 and $28 \%$ arabinan conversion, which are 64 and $56 \%$ lower than that with enzyme mix A, after 24 and $72 \mathrm{~h}$, respectively. On the other hand, no significant differences in arabinan conversion were obtained with mix $\mathrm{F}$ in comparison to mix A.

Hydrolysis of AFEX-treated corn stover using purified enzyme cocktail mixtures showed that no significant increase in sugar conversion was achieved replacing enzyme mix A with mix B, mix E and mix F (Table 5). On the other hand, enzyme mix $\mathrm{C}$ and mix D gave $8 \%$ higher glucan conversion after $24 \mathrm{~h}$ when compared to enzyme mix A. However, the sugar conversion decreased after $72 \mathrm{~h}$ hydrolysis. Enzyme mix C and mix D gave 57.4 and $63.2 \%$ arabinan conversion, respectively, after $24 \mathrm{~h}$, which is 8.5 and $17 \%$ higher than that with $\operatorname{mix}$ A.

It is worth noting that the evolved variant $\mathrm{rPoAbf}$ F435Y7Y446F gave a better arabinan conversion than the wild-type enzyme for both the biomasses.

\section{Synergy between commercial enzyme cocktail and purified enzymes (rPoAbf and/or rCelstrep)}

To study synergy between the commercial enzyme cocktail Novozymes Cellic ${ }^{\circledR}$, Ctec3 and Htec3, and the purified enzymes rPoAbf, its evolved mutant rPoAbf F435Y/Y446F and rCelstrep, hydrolysis of AFEX-pretreated A. donax and corn stover was carried out adding each tested enzyme or their 
Table 4 A. donax sugar conversion in $50 \mathrm{mM}$ citrate buffer $\mathrm{pH} 4.5$ and $T 50{ }^{\circ} \mathrm{C}$, for 24 and $72 \mathrm{~h}$. The values represent the means $\pm \mathrm{SD}$ of three replicates. Different superscript letters after the values indicate significant differences $(P \leq 0.05)$ on the same column within samples collected after 24 or $72 \mathrm{~h}$

Enzyme mixture Purified enzyme cocktail

Glucan conversion (\%) Xylan conversion (\%) Arabinan conversion (\%)

\begin{tabular}{|c|c|c|}
\hline \multicolumn{3}{|c|}{$24 \mathrm{~h}$ hydrolysis } \\
\hline Mix A & CBHI-CBHII- $\beta$ G-LX3-LX4-L $\beta X+$ EGI \& LarbF & $14.2 \pm 1.6^{\mathrm{a}}$ \\
\hline Mix B & CBHI-CBHII- $\beta$ G-LX3-LX4-L $\beta X+$ rCelstrep \& LarbF & $11.8 \pm 2.9^{\mathrm{a}}$ \\
\hline Mix C & CBHI-CBHII- $\beta$ G-LX3-LX4-L $\beta X+$ EGI \& rPoAbf & $16.9 \pm 0.2^{\mathrm{b}}$ \\
\hline Mix D & $\begin{array}{l}\text { CBHI-CBHII- } \beta \text { G-LX3-LX4-L } \beta \text { X+EGI \& rPoAbf } \\
\text { F435Y/Y446F }\end{array}$ & $17.5 \pm 1.8^{\mathrm{c}}$ \\
\hline Mix E & CBHI-CBHII- $\beta$ G-LX3-LX4-L $\beta X+$ rCelstrep \& rPoAbf & $16.6 \pm 0.3^{\mathrm{b}}$ \\
\hline Mix F & $\begin{array}{l}\text { CBHI-CBHII- } \beta \text { G-LX3-LX4-L } \beta X+\text { rCelstrep \& rPoAbf } \\
\text { F435Y/Y446F }\end{array}$ & $16.4 \pm 0.1^{\mathrm{b}}$ \\
\hline \multicolumn{3}{|c|}{$72 \mathrm{~h}$ hydrolysis } \\
\hline Mix A & CBHI-CBHII- $\beta$ G-LX3-LX4-L $\beta X+$ EGI \& LarbF & $24.1 \pm 1.1^{\mathrm{b}}$ \\
\hline Mix B & CBHI-CBHII- $\beta$ G-LX3-LX4-L $\beta X+$ rCelstrep \& LarbF & $28.5 \pm 2.6^{\mathrm{c}}$ \\
\hline Mix C & CBHI-CBHII- $\beta$ G-LX3-LX4-L $\beta X+$ EGI \& rPoAbf & $24.6 \pm 1.5^{\mathrm{b}}$ \\
\hline Mix D & $\begin{array}{l}\text { CBHI-CBHII- } \beta \text { G-LX3-LX4-L } \beta \text { X+EGI \& rPoAbf } \\
\text { F435Y/Y446F }\end{array}$ & $61.6 \pm 0.4^{\mathrm{d}}$ \\
\hline Mix E & CBHI-CBHII- $\beta$ G-LX3-LX4-L $\beta X+$ rCelstrep \& rPoAbf & $20.6 \pm 1.2^{\mathrm{a}}$ \\
\hline Mix F & $\begin{array}{l}\text { CBHI-CBHII- } \beta \text { G-LX3-LX4-L } \beta X+\text { rCelstrep \& rPoAbf } \\
\text { F435Y/Y446F }\end{array}$ & $22.1 \pm 1.2^{\mathrm{a}}$ \\
\hline
\end{tabular}

combinations (rCelstrep and rPoAbf or rCelstrep and rPoAbf F435Y/Y446F) to the Novozymes cocktail.

The glucan conversion using commercial enzyme cocktail was found to be higher when compared to supplementation with wild-type rPoAbf or its evolved variant or rCelstrep or both enzymes (Fig. 3a). These results could be explained by hypothesizing an anti-synergism between the activity of (hemi)cellulases in commercial mixture and purified ones. The negative level of synergism was already described for commercial enzymes involved in biomass degradation and purified ones (Woodward J 1991; Morrison 2014).

Supplementing rPoAbf and its evolved variant gave $70 \%$ xylan conversion, $7 \%$ higher than that obtained by the commercial preparation. After 6 days of hydrolysis, $80 \%$ xylan conversion was achieved when $\mathrm{rPoAbf}$ F435Y/Y446F was used along with commercial enzymes (Fig. 3b). The arabinan conversion was also improved by supplementing $\mathrm{rPoAbf}$ or variant to the commercial enzyme cocktail by 27 and $36 \%$, respectively, after $24 \mathrm{~h}$ of hydrolysis (Fig. 3c). A maximum arabinan conversion of $80 \%$ was achieved after 6 days of hydrolysis when rPoAbf was added to commercial enzymes.

In the case of corn stover, no appreciable increase in glucan conversion was observed when commercial preparation was supplemented with wild-type rPoAbf or its variant or rCelstrep or both enzymes (data not shown). However, $99 \%$ xylan conversion was achieved after $24 \mathrm{~h}$ of hydrolysis with commercial enzymes supplemented with rPoAbf wild type (Fig. 4a). The same xylan conversion was achieved using commercial preparation and commercial preparation in combination with $\mathrm{rPoAbf} \mathrm{F} 435 \mathrm{Y} / \mathrm{Y} 446 \mathrm{~F}$ or rCelstrep or both
Fig. 2 Arabinan conversion after 24 and $72 \mathrm{~h}$ hydrolysis of ammonia fibre expansion (AFEX)-treated A. donax with the enzymatic mixtures reported in Table 4

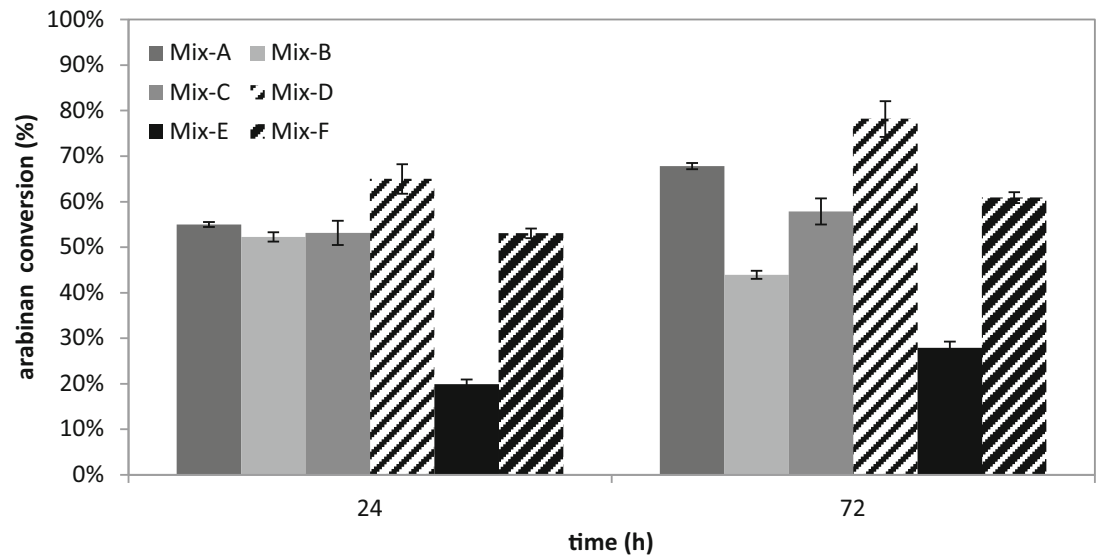


Table 5 Corn stover sugar conversion in $50 \mathrm{mM}$ citrate buffer $\mathrm{pH} 4.5, T 50^{\circ} \mathrm{C}$. The values represent the means $\pm \mathrm{SD}$ of three replicates. Different superscript letters after the values indicate significant differences $(P \leq 0.05)$ on the same column within samples collected after 24 or $72 \mathrm{~h}$

\begin{tabular}{|c|c|c|c|c|}
\hline Enzyme mixture & Purified enzyme cocktail & Glucan conversion $(\%)$ & Xylan conversion $(\%)$ & Arabinan conversion $(\%)$ \\
\hline \multicolumn{5}{|l|}{$24 \mathrm{~h}$ hydrolysis } \\
\hline Mix A & CBHI-CBHII- $\beta$ G-LX3-LX4-L $\beta X+$ EGI \& LarbF & $39.6 \pm 0.8^{\mathrm{c}}$ & $67.1 \pm 1.2^{\mathrm{c}}$ & $52.5 \pm 1.3^{\mathrm{b}}$ \\
\hline Mix B & CBHI-CBHII- $\beta$ G-LX3-LX4-L $\beta X+$ rCelstrep \& LarbF & $32.7 \pm 0.1^{\mathrm{a}}$ & $67.5 \pm 0.1^{\mathrm{c}}$ & $53.5 \pm 0.1^{\mathrm{bc}}$ \\
\hline Mix $\mathrm{C}$ & CBHI-CBHII- $\beta$ G-LX3-LX4-L $\beta X+$ EGI \& rPoAbf & $42.8 \pm 0.7^{\mathrm{d}}$ & $72.8 \pm 1.1^{\mathrm{d}}$ & $57.4 \pm 0.8^{\mathrm{d}}$ \\
\hline Mix D & $\begin{array}{l}\text { CBHI-CBHII- } \beta \text { G-LX3-LX4-L } \beta \text { X+EGI \& rPoAbf } \\
\text { F435Y/Y446F }\end{array}$ & $42.7 \pm 0.2^{\mathrm{d}}$ & $73.6 \pm 0.4^{\mathrm{d}}$ & $63.2 \pm 0.2^{\mathrm{e}}$ \\
\hline Mix E & CBHI-CBHII- $\beta$ G-LX3-LX4-L $\beta X+$ rCelstrep \& rPoAbf & $38.3 \pm 1.1^{\mathrm{b}}$ & $59.6 \pm 1.2^{\mathrm{a}}$ & $54.1 \pm 2.0^{\mathrm{c}}$ \\
\hline Mix F & $\begin{array}{l}\text { CBHI-CBHII- } \beta \text { G-LX3-LX4-L } \beta X+\text { rCelstrep \& rPoAbf } \\
\text { F435Y/Y446F }\end{array}$ & $39.2 \pm 0.7^{\mathrm{c}}$ & $65.5 \pm 1.1^{\mathrm{b}}$ & $16.4 \pm 1.2^{\mathrm{a}}$ \\
\hline \multicolumn{5}{|l|}{$72 \mathrm{~h}$ hydrolysis } \\
\hline Mix A & CBHI-CBHII- $\beta$ G-LX3-LX4-L $\beta X+$ EGI \& LarbF & $61.4 \pm 1.2^{\mathrm{f}}$ & $82.2 \pm 1.5^{\mathrm{e}}$ & $64.2 \pm 2.0^{\mathrm{e}}$ \\
\hline Mix B & CBHI-CBHII- $\beta$ G -LX3-LX4-L $\beta X+$ rCelstrep \& LarbF & $56.3 \pm 0.7^{\mathrm{e}}$ & $83.6 \pm 2.1^{\mathrm{e}}$ & $14.4 \pm 0.2^{\mathrm{a}}$ \\
\hline Mix $\mathrm{C}$ & CBHI-CBHII- $\beta$ G -LX3-LX4-L $\beta X+$ EGI \& rPoAbf & $11.7 \pm 1.0^{\mathrm{a}}$ & $77.0 \pm 1.2^{\mathrm{d}}$ & $56.0 \pm 0.1^{\mathrm{c}}$ \\
\hline Mix D & $\begin{array}{l}\text { CBHI-CBHII- } \beta \text { G -LX3-LX4-L } \beta X+\text { EGI \& rPoAbf } \\
\text { F435Y/Y446F }\end{array}$ & $41.2 \pm 0.6^{\mathrm{b}}$ & $73.4 \pm 0.4^{\mathrm{c}}$ & $63.5 \pm 0.2^{\mathrm{e}}$ \\
\hline Mix E & CBHI-CBHII- $\beta$ G -LX3-LX4-L $\beta X+$ rCelstrep \& rPoAbf & $47.2 \pm 0.8^{\mathrm{c}}$ & $57.9 \pm 0.2^{\mathrm{a}}$ & $59.2 \pm 1.4^{\mathrm{d}}$ \\
\hline Mix F & $\begin{array}{l}\text { CBHI-CBHII- } \beta \text { G -LX3-LX4-L } \beta X+\text { rCelstrep \& rPoAbf } \\
\text { F435Y/Y446F }\end{array}$ & $48.7 \pm 1.2^{\mathrm{d}}$ & $65.5 \pm 0.5^{\mathrm{b}}$ & $27.2 \pm 0.2^{\mathrm{b}}$ \\
\hline
\end{tabular}

enzymes after 6 days of hydrolysis. Supplementation of commercial enzyme cocktail with rPoAbf gave $70 \%$ of arabinan conversion after $24 \mathrm{~h}$ of hydrolysis (Fig. 4b).

\section{Discussion}

This study was focused on pretreatment and saccharification of the giant reed (A. donax L.) using corn stover as reference lignocellulosic biomass. A. donax is a biomass crop that can be cultivated with high yields in marginal areas not suitable for the traditional food crops, gaining at the same time several environmental benefits such as soil protection from erosion, $\mathrm{C}$ storage into the soil and phytoremediation of polluted soils (Fagnano et al. 2015; Forte et al. 2015).

The data of macromolecular composition of $A$. donax and corn stover used in this study was revealed to be in agreement with data reported in previous studies (Caparrós et al. 2007; Li et al. 2011; Scordia et al. 2012).

The pretreatment methods so far tested and reported in literature for $A$. donax include the steam explosion, acidcatalyzed steam explosion and ammonia soaking (De Bari et al. 2013; Van Den Brink et al. 2013; Marcolongo et al. 2014). However, most of these methods solubilize large portions of xylan from this biomass.

On the other hand, ammonia fibre expansion (AFEX) is a dry to dry process which preserves all the original carbohydrates (Gao et al. 2011 and 2013; Li et al. 2011; Harun et al. 2013; Uppugundla et al. 2014) without any loss. This pretreatment has never been used for $A$. donax. Therefore, this pretreatment process was selected for this study, in order to avoid the loss of the significant amounts of xylan present in the investigated biomass (Table 2).

Corn stover was chosen as reference lignocellulosic biomass because AFEX pretreatment had been previously carried out on it in several works giving high yields of both glucose and xylose (Balan et al. 2009; Li et al. 2011). It is worthy of note that the best AFEX condition selected in this study for the biomass of $A$. donax (condition 2: $130^{\circ} \mathrm{C}, 1 \mathrm{~kg}$ ammonia/ $1 \mathrm{~kg}$ dry biomass and $60 \%$ of moisture content) was the same pretreatment condition previously adopted for corn stover (Gao et al. 2011).

The effect of the $\alpha$-L-arabinofuranosidase rPoAbf, its evolved mutant $\mathrm{rPoAbf} \mathrm{F} 435 \mathrm{Y} / \mathrm{Y} 446 \mathrm{~F}$ and the cellulase rCelStrep, to enhance the saccharification of the pretreated giant reed (A. donax L.) in substitution of the purified enzymes LarbF or EGI, respectively, was tested in bioconversion of AFEX-pretreated A. donax. Moreover, synergy between commercial enzyme cocktail Novozymes Cellic ${ }^{\circledR}, \mathrm{Ctec} 3$ and Htec3, and rPoAbf, rPoAbf F435Y/Y446F and rCelStrep in hydrolysis of AFEX-pretreated A. donax and corn stover was also investigated. Corn stover was the reference feedstock for all the saccharification experiments.

As the most positive effects observed for $A$. donax conversion, the use of the rPoAbf F435Y/Y446F within the mixture of purified enzymes allowed achieving better glucan, xylan and arabinan conversions than LarbF and rPoAbf wild type. In particular, $\mathrm{rPoAbf} \mathrm{F} 435 \mathrm{Y} / \mathrm{Y} 446 \mathrm{~F}$ gave a glucan conversion after $72 \mathrm{~h} 2.5$ times higher than that obtained with the other enzymes, a xylan conversion after $24 \mathrm{~h} 16 \%$ higher than that 
Fig. 3 Glucan (a), xylan (b) and arabinan (c) conversion of AFEXtreated $A$. donax achieved using commercial enzyme preparation Novozymes Cellic ${ }^{\circledR}, 60 \%$ Ctec3 and $40 \%$ Htec 3 , with or without addition of rPoabf, its variant F435Y/Y446F, rCelstrep or a combination of these enzymes
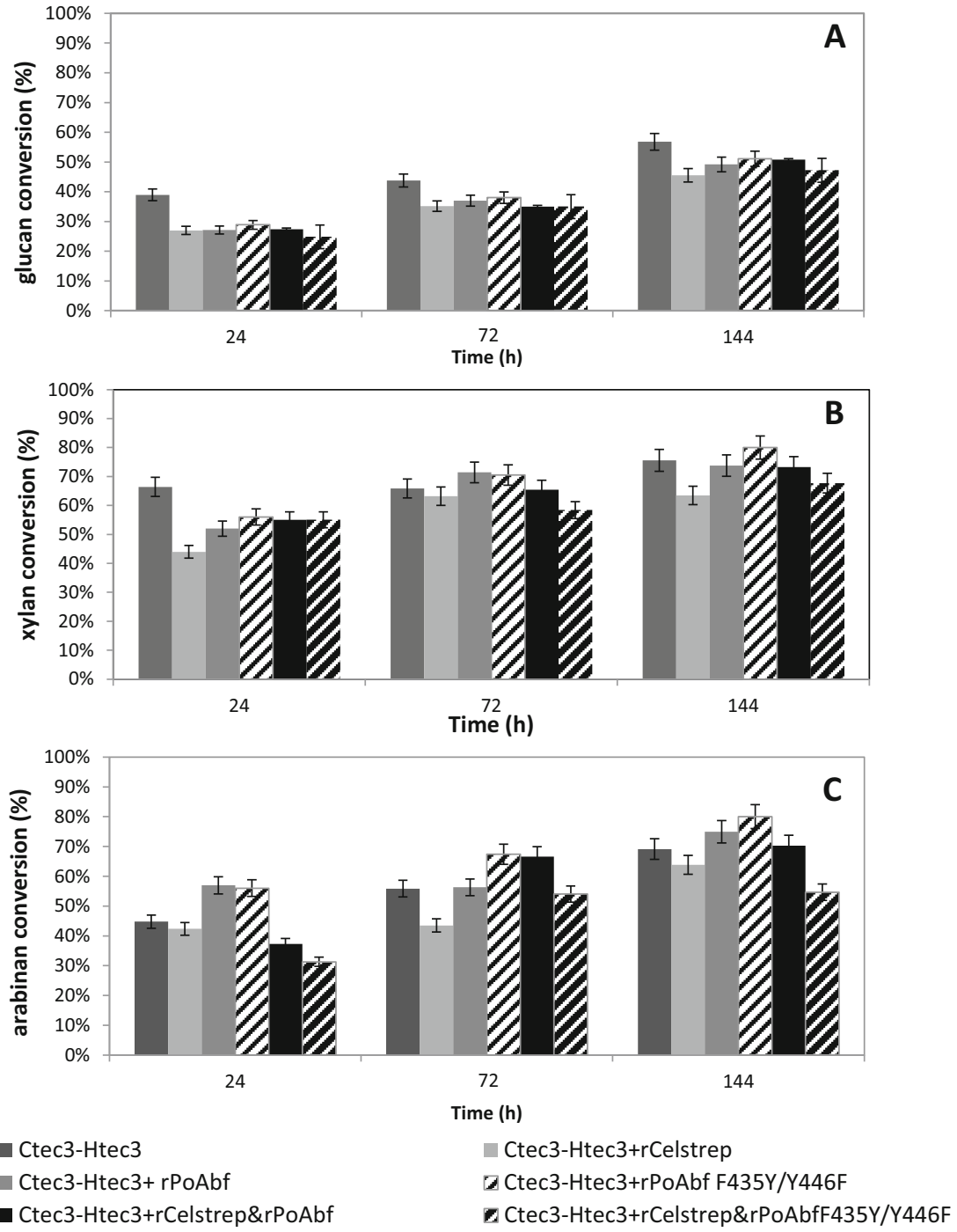

obtained with LarbF and an arabinan conversion after $72 \mathrm{~h} 15$ and $26 \%$ higher than that obtained with LarbF and the wildtype $\mathrm{rPoAbf}$, respectively. The improvement of glucan conversion with the enzymatic cocktail containing rPoAbf F435Y/Y446F can be explained with the enhancement of the accessibility of this polysaccharide due to xylan hydrolysis, as previously reported (Polizeli et al. 2005).

The higher glucan conversion yield obtained substituting EGI with rCelstrep in the mixture of purified enzymes suggests a synergistic role of the bacterial cellulase rCelstrep when mixed with the fungal cellulases $\mathrm{CBHI}$, CBHII and $\beta G$ on glucan conversion. The use of Celstrep in combination with $\mathrm{rPoAbf}$ and its variant gave lower sugar conversion than those achieved using rPoAbf and its variant in combination with EGI, which could indicate a lower synergism between bacterial cellulase and fungal arabinofuranosidase than that between fungal cellulase and arabinofuranosidase. Moreover, this effect was more pronounced at longer times, which could be due to the loss of degree of synergy during the hydrolysis caused by structural modifications of the substrate as reported by Andersen et al. (2008) or saturation of sites for enzyme activity as proposed by Boisset et al. (2001).

As regards corn stover biomass, no significant improvement of sugar conversion was observed when the reference mixture of purified enzymes (mix A previously optimized for this biomass by Gao et al. 2011) was replaced by the other purified enzymes tested in this work.

The comparison of the effects of rPoAbf wild type and $\mathrm{rPoAbf} \mathrm{F} 435 \mathrm{Y} / \mathrm{Y} 446 \mathrm{~F}$ in the presence of rCelstrep showed that the use of rPoAbf wild type led to the highest arabinan conversion from corn stover (mix E), while for A. donax biomass, the best conversion was obtained using rPoAbf F435Y/ Y446F (mix F). These results could be explained by hypothesizing a diverse specificity and synergism of the enzymes towards the different biomasses.

As regards A. donax saccharification experiments performed with commercial enzyme cocktail Novozymes 
Fig. 4 Xylan (a) and arabinan (b) conversion of AFEX-treated corn stover achieved using commercial enzyme preparation Novozymes Cellic ${ }^{\circledR}, 60 \%$ Ctec 3 and $40 \%$ Htec3, with or without addition of rPoabf, its variant $\mathrm{F} 435 \mathrm{Y} / \mathrm{Y} 446 \mathrm{~F}$, rCelstrep or a combination of these
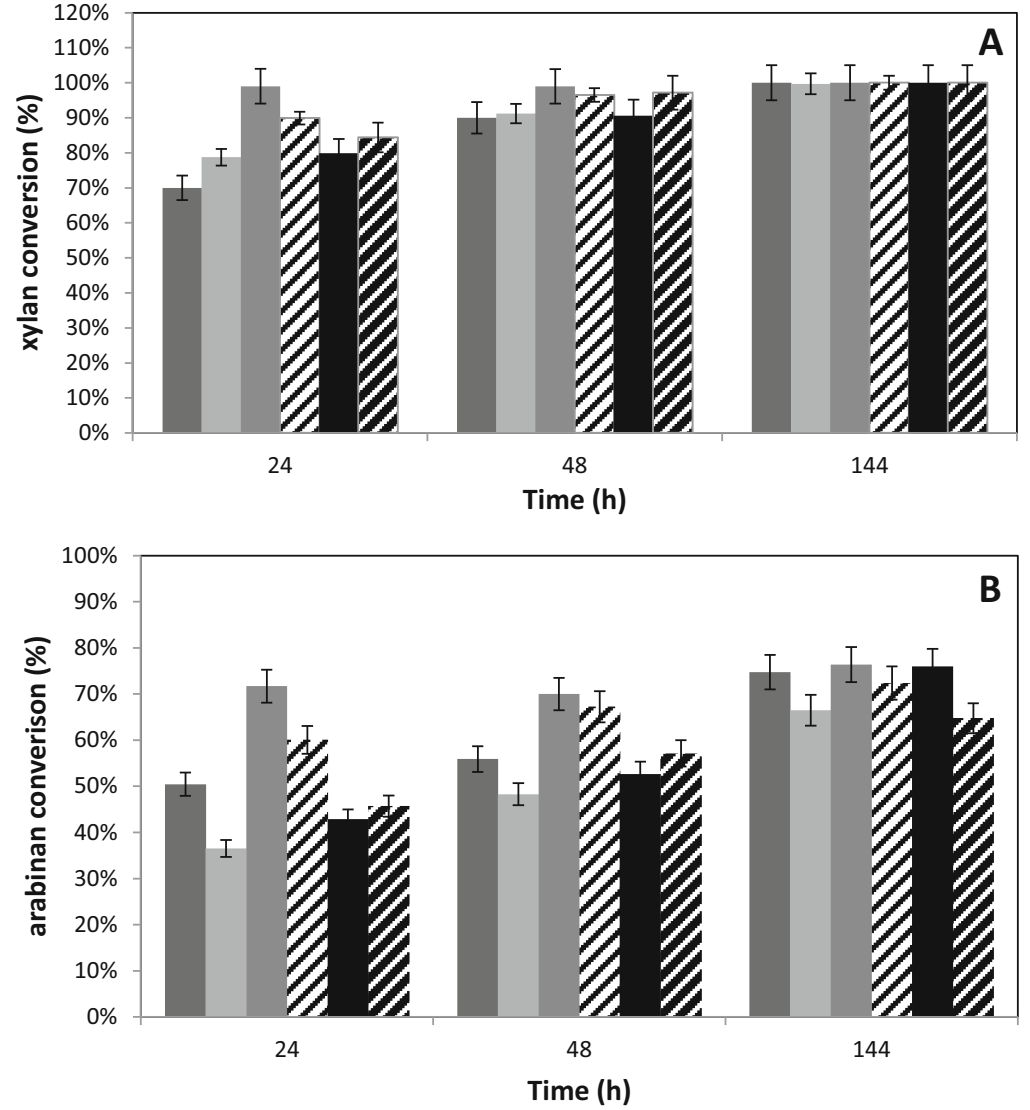

- Ctec3-Htec3

- Ctec3-Htec3+rCelstrep

- Ctec3-Htec3+rPoAbf

$>$ Ctec3-Htec3+rPoAbf F435Y/Y446F

- Ctec3-Htec3+rCelstrep\&rPoAbfF435Y/Y446F

a Ctec3-Htec3+rCelstrep\&rPoAbf
Cellic ${ }^{\circledR}$, Ctec3 and Htec3, and rPoAbf, its evolved variant rPoAbf F435Y/Y446F and rCelStrep, no significant increase in sugar conversion was observed (Fig. 3a-c). However, it is worthy to note that supplementing rPoAbf F435Y/Y446F, the percentage of xylan and arabinan conversion increased, reaching the highest conversion ( $80 \%$ for both sugars) after 6 days of hydrolysis. Comparing the data of conversion of A. donax pretreated by aqueous ammonia soaking (Marcolongo et al. 2014), similar xylan conversion was achieved by using the commercial mix in combination with rPoAbf and its evolved mutant after $72 \mathrm{~h}$ of hydrolysis. Even if the xylan hydrolysis described by Marcolongo et al. (2014) appeared to be faster than that reported in this work, it is worth to note that the amount of arabinofuranosidase enzymes in this manuscript (1.5 U/g expressed as units of purified enzyme, assayed against the substrate pNP-a-L-arabinofuranoside as previously described in Amore et al. 2012a, per gram of pretreated biomass) is lower than that $(27.2 \mathrm{U} / \mathrm{g})$ used in Marcolongo et al. (2014).

Also, in the case of corn stover, positive effects were observed in xylan and arabinan conversion when the enzymes tested in this work were added to the commercial enzyme cocktail Novozymes Cellic ${ }^{\circledR}$, Ctec3 and Htec3. The $99 \%$ xylan conversion was achieved in $24 \mathrm{~h}$ when rPoAbf wild type was supplemented to the commercial enzymes. The same xylan conversion was achieved using commercial preparation and commercial preparation in combination with $\mathrm{rPoAbf}$ F435Y/Y446F or rCelstrep or both enzymes after 6 days of hydrolysis. Interestingly, these data highlight that by adding rPoAbf wild type, the hydrolysis of corn stover seems to be faster than that with other preparations. These results could be due to the diverse degree of synergism among the enzymes due to different substrate proprieties as previously reported (Andersen et al. 2008; Van Dyk and Pletschke 2012).

All these data confirm the importance of using accessory enzymes like arabinofuranosidases to achieve high xylan conversion yield since they increase accessibility of xylan acting on side chain of hemicellulose and demonstrate the effectiveness of the arabinofuranosidase from the fungus $P$. ostreatus rPoAbf and, even more, of its evolved mutant rPoAbf F435Y/ Y446F. It is worth to note that the use of the purified enzyme cocktail containing rPoAbf F435Y/Y446F allowed achieving higher or similar glucan, xylan and arabinan conversion after $72 \mathrm{~h}$ of hydrolysis $(62,63$ and $80 \%$ ) than those 
achieved after the same time of hydrolysis with commercial enzymes Novozymes Cellic ${ }^{\circledR}$, Ctec3 and Htec3 (44, 66 and $55 \%)$.

Acknowledgments This work was supported by a grant from the Ministero dell'Università e della Ricerca Scientifica - Industrial Research Project "Integrated agro-industrial chains with high energy efficiency for the development of eco-compatible processes of energy and biochemicals production from renewable sources and for the land valorization (EnerbioChem)" PON01_01966, funded in the frame of Operative National Programme Research and Competitiveness 2007-2013 D. D. Prot. n. 01/Ric. 18.1.2010. We thank Lucigen enzyme company for supplying the research enzymes and Novozyme for supplying Cte3 and Htec3 enzymes for this work. The authors also thank Dr. Valeria Ventorino of the Department of Agriculture, University of Naples "Federico II", for the support in the statistical treatment of data.

\section{Compliance with ethical standards}

Conflict of interest The authors declare that they have not competing interests.

Open Access This article is distributed under the terms of the Creative Commons Attribution 4.0 International License (http:// creativecommons.org/licenses/by/4.0/), which permits unrestricted use, distribution, and reproduction in any medium, provided you give appropriate credit to the original author(s) and the source, provide a link to the Creative Commons license, and indicate if changes were made.

\section{References}

Amore A, Amoresano A, Birolo L, Henrissat B, Leo G, Palmese A, Faraco V (2012a) A family GH51 $\alpha$-L-arabinofuranosidase from Pleurotus ostreatus: identification, recombinant expression and characterization. Appl Microbiol Biotechnol 94(4):995-1006

Amore A, Pepe O, Ventorino V, Birolo L, Giangrande C, Faraco V (2012b) Cloning and recombinant expression of a cellulase from the cellulolytic strain Streptomyces sp. G12 isolated from compost. Microb Cell Fact 11:164

Andersen N, Johansen KS, Michelsen M, Stenby EH, Krogh KB, Olsson L (2008) Hydrolysis of cellulose using mono-component enzymes shows synergy during hydrolysis of phosphoric acid swollen cellulose (PASC), but competition on Avicel. Enzyme Microb Technol 42:362-370

Balan V, Da Costa SL, Chundawat SPS, Marshall D, Sharma LN, Chambliss CK, Dale BE (2009) Enzymatic digestibility and pretreatment degradation products of AFEX-treated hardwoods (Populus nigra). Biotechnol Prog 25:365-375

Bals B, Rogers C, Jin M, Balan V, Dale BE (2010) Evaluation of ammonia fibre expansion (AFEX) pretreatment for enzymatic hydrolysis of switchgrass harvested in different seasons and locations. Biotechnol Biofuels 3:1

Boisset C, Petrequin C, Chanzy H, Henrissat B, Schulein M (2001) Optimized mixtures of recombinant Humicola insolens cellulases for the biodegradation of crystalline cellulose. Biotechnol Bioeng 72(3):339-45

Caparrós S, Ariza J, Lopez F, Diaz MJ (2007) Optimizing cellulosic paper obtained from Arundo donax L. under hydrothermal treatment. J Ind Eng Chem 13(3):465-473
De Bari I, Liuzzi F, Villone A, Braccio G (2013) Hydrolysis of concentrated suspensions of steam pretreated Arundo donax. Appl Energy 102:179-189

Diodato N, Fagnano M, Alberico I (2009) CliFEM-climate forcing and erosion response modelling at long-term Sele River research basin (southern Italy). Nat Hazards Earth Syst Sci 9:1693-1702

Diodato N, Fagnano M, Alberico I (2011) Geospatial-and-visual modeling for exploring sediment source areas across the Sele river landscape, Italy. Ital J Agron 6:85-92

Fagnano M, Diodato N, Alberico I, Fiorentino N (2012) An overview of soil erosion modeling compatible with RUSLE approach. Rend Fis Acc Lincei 23:69-80

Fagnano M, Impagliazzo A, Mori M, Fiorentino N (2015) Agronomic and environmental impacts of giant reed (Arundo donax L.): results from a long-term field experiment in hilly areas subject to soil erosion. Bioenergy Res 8:415-422

Fiorentino N, Fagnano M, Adamo P, Impagliazzo A, Mori M, Pepe O, Pepe O, Ventorino V, Zoina A (2013) Assisted phytoextraction of heavy metals: compost and Trichoderma effects on giant reed (Arundo donax L.) uptake and soil N-cycle microflora. Ital J Agron 8:244-254

Fiorentino N, Impagliazzo A, Ventorino V, Pepe O, Piccolo A, Fagnano M (2010) Biomass accumulation and heavy metal uptake of giant reed on polluted soil in southern Italy. J Biotechnol 150(S1):261

Forte A, Zucaro A, Fagnano M, Bastianoni S, Basosi R, Fierro A (2015) LCA of Arundo donax L. lignocellulosic feedstock production under Mediterranean conditions: a three-year study. Biomass Bioenergy 73:32-47

Gao D, Chundawat SPS, Krishnan C, Balan V, Dale BE (2010a) Mixture optimization of six core glycosyl hydrolases for maximizing saccharification of ammonia fiber expansion (AFEX) pretreated corn stover. Bioresour Technol 101:2770-2781

Gao D, Chundawat SPS, Liu T, Hermanson S, Gowda K, Brumm P, Dale BE, Balan V (2010b) Strategy for identification of novel fungal and bacterial glycosyl hydrolase hybrid mixtures that can efficiently saccharify pretreated lignocellulosic biomass. Bioenergy Res 3:67-81

Gao D, Uppugundla N, Chundawat SPS, Yu X, Hermanson S, Gowda K, Brumm P, Mea D, Balan V, Dale BE (2011) Hemicellulases and auxiliary enzymes for improved conversion of lignocellulosic biomass to monosaccharides. Biotechnol Biofuels 4(1):5

Giacobbe S, Vincent F, Faraco V (2014) Development of an improved variant of GH51 $\alpha$-1-arabinofuranosidase from Pleurotus ostreatus by directed evolution. New Biotechnol 31(3):230-236

Hames B, Ruiz R, Scarlata C, Sluiter A, Sluiter J, Templeton D (2008) Preparation of samples for compositional analysis. National Renewable Energy Laboratory, Golden, CO, USA: NREL Laboratory Analytical

Harun S, Balan V, Takriff MS, Hassan O, Jahim J, Dale BE (2013) Performance of AFEX pretreated rice straw as source of fermentable sugars: the influence of particle size. Biotechnol Biofuels 6:40

Hermann BG, Blok K, Patel MK (2007) Producing bio-based bulk chemicals using industrial biotechnology saves energy and combats climate change. Environ Sci Technol 41(22):7915-21

Kajaste R (2014) Chemicals from biomass e managing greenhouse gas emissions in biorefinery production chains e a review. J Clean Prod. doi:10.1016/j.jclepro.2014.03.070

Kobayashi H, Fukuoka A (2013) Synthesis and utilization of sugar compounds derived from lignocellulosic biomass. Green Chem 15(7): $1740-1763$

Kumar P, Barrett DM, Delwiche MJ, Stroeve P (2009) Methods for pretreatment of lignocellulosic biomass for efficient hydrolysis and biofuel production. Ind Eng Chem Res 48:3713-3729

Li C, Cheng G, Balan V, Kent MS, Ong M, Chundawat SPS, daCosta SL, Melnichenko YB, Dale BE, Simmons BA, Singh S (2011) Influence of physico-chemical changes on enzymatic digestibility of ionic 
liquid and AFEX pretreated corn stover. Bioresour Technol 102(13): 6928-6936

Marcolongo L, Ionata E, La F, Amore A, Giacobbe S, Pepe O, Faraco V (2014) The effect of Pleurotus ostreatus arabinofuranosidase and its evolved variant in lignocellulosic biomasses conversion. Fungal Genet Biol 72:162-167

Morrison DG (2014) Lignocellulosic waste degradation using enzyme synergy with commercially available enzymes and Clostridium cellulovorans xylanaseA and mannanase A. Thesis Masters M.Sc. http://hdl.handle.net/10962/d1013292

Murnen HK, Balan V, Chundawat SPS, Bals B, Sousa LD, Dale BE (2007) Optimization of ammonia fiber expansion (AFEX) pretreatment and enzymatic hydrolysis of Miscanthus x giganteus to fermentable sugars. Biotechnol Prog 23:846-850

Polizeli MLTM, Rizzatti ACS, Monti R, Terenzi HF, Jorge JA, Amorim DS (2005) Xylanases from fungi: properties and industrial applications. Appl Microbiol Biotechnol 67(5):577-591

Scheidel A, Sorman AH (2012) Energy transitions and the global land rush: ultimate drivers and persistent consequences. Glob Environ Chang 22:588-595

Scordia D, Cosentino SL, Lee JW, Jeffries TW (2012) Bioconversion of giant reed (Arundo donax L.) hemicellulose hydrolysate to ethanol by Scheffersomyces stipitis CBS6054. Biomass Bioenergy 39: 296-305

Sluiter A, Hames B, Ruiz R, Scarlata C, Sluiter J, Templeton D, Crocker D (2005a) Determination of structural carbohydrates and lignin in biomass. National Renewable Energy Laboratory, Golden, CO, USA: NREL Laboratory Analytical

Sluiter A, Hames B, Ruiz R, Scarlata C, Sluiter J, Templeton D (2005b) Determination of ash in biomass. National Renewable Energy
Laboratory, Golden, CO, USA: NREL Laboratory Analytical Procedures

Sluiter A, Hames B, Hyman D, Payne D, Ruiz R, Scarlata C, Sluiter J, Templeton D, Wolfe J (2008) Determination of total solids in biomass and total dissolved solids in liquid process samples. National Renewable Energy Laboratory, Golden, CO, USA: NREL Laboratory Analytical

Taherzadeh MJ, Keikhosro K (2007) Enzyme-based hydrolysis processes for ethanol from lignocellulosic materials: a review. Bioresources 2: 707-738

Uppugundla N, daCosta SL, Chundawat SPS, Yu X, Simmons B, Singh S, Gao X, Kumar R, Wyman CE, Dale BE, Balan V (2014) A comparative study of ethanol production using dilute acid, ionic liquid and AFEX ${ }^{\mathrm{TM}}$ pretreated corn stover. Biotechnol Biofuels 13:7-72

Van Den Brink J, Van Muiswinkel GCJ, Theelen B, Hinz SW, De Vries RP (2013) Efficient plant biomass degradation by thermophilic fungus Myceliophthora heterothallica. Appl Environ Microbiol 79(4): 1316-1324

Van Dyk JS, Pletschke BI (2012) A review of lignocellulose bioconversion using enzymatic hydrolysis and synergistic cooperation between enzymes - factors affecting enzymes, conversion and synergy. Biotechnol Adv 30:1458-1480

Wettstein SG, Alonso DM, Gu EI, Dumesic JA (2012) A roadmap for conversion of lignocellulosic biomass to chemicals and fuels. Curr Opin Chem Eng 1:218-224

Woodward J (1991) Synergism in cellulase systems. Biores Technol 36: $67-75$ 